\title{
Urgensi Legislasi Undang-undang tentang Minuman Beralkohol di Indonesia
}

\author{
Iman Nur Hidayat, Agus Hermanto \\ Fakultas Syari'ah UNIDA, Fakultas Syari'ah UIN Raden Intan Lampung \\ E-mail: imanhaiban@yahoo.co.id, gusher.sulthani@radenintan.ac.id
}

\begin{abstract}
Abstrak: Kajian tentang Rencana RUU menjadi penting, di satu sisi bahwa telah ada Fatwa MUI Nomor 11 Tahun 2019 tentang Hukum Alkohol, namun demikian, bahwa fatwa tidaklah mengikat dan hanya berlaku bagi kaum muslimin di Indonesia, realitanya minuman beralkohol ucap kali ditemukan menjadi tradisi dan kebiasaan dalam acara-acara di wilayah-wilayah tertentu, seperti Sulawesi dan Sumatra Barat, untuk dapat memberlakukan sebuah aturan secara legal, mengikat kepada semua masyarakat, maka perlu dibuat Undang-Undang tentang Larangan Minuman Beralkohol, karena dengan kebiasaan minuman beralkohol, banyak meresahkan masyarakat, merugikan negara, banyaknya kecelakaan lalu lintas serta merusak generasi. Melihat realita yang ada, maka perlu kiranya Indonesia menggas RUU tentang larangan minuman beralkohol, dengan tujuan agar masyarakat Indoesia senantiasa memahami kemudharatan yang terjadi akibat minuman beralkohol. Kajian ini merupakan jenis kualitatif, dalam bentuk studi pustaka (library reseach) yang membahas tentang kemudharatan minuman beralkohol dalam tinjaun filosofishistoris dengan pendekatan maqasid al-syari'ah. Tinjauan maqasid al-Syari'ah terhadap keharaman minuman beralkohol sebagaimana keharaman khamr dalam proses analogi hukum bertujuan untuk; Pertama, Mengambil kemaslahatan dan meniadakan kemudharatan, Kedua, bentuk saad al-Dzari'ah yaitu mencegah celah untuk melakukan tindakan yang membawa kemudharatan lebih besar dengan kaidah dar'ul mafasidi muqaddamun 'ala jalbil mashalih (mencegah kemudhartan lebih diutamakan daripada mengambil kemaslahatan). Hal ini dilakukan dmemi melindungi agama, jiwa, akal, nasab dan juga harta. Dari sinilah dipastikan bahwa segala minuman yang mendatangkan kemudharatan sebagaimana khamr dihukumi haram sebagaimana khamr, karena memiliki 'illat (argumen) hukum yang sama.
\end{abstract}

Kata Kunci: Urgensi, legislasi, minuman beralkohol. 


\section{Pendahuluan}

Secara historis, minuman beralkohon telah dikenal 500 an tahun silam, bahkan minuman beralkohol telah menjadi kehidupan sehari-hari bagi masyarakat dan kebudayaan tertentu. Sedangkan di Indonesia, minuman beralkohon ucap kali, seperti brem cair, tuak, saguer, dan ciu. Sedangkan di masing-masing negara memiliki corak merek maupun nama yang berbeda-beda. ${ }^{1}$ Kebiasaan mengonsumsi minuman beralkohol (modern, tradisional ${ }^{2}$ ataupun oplosan) dapat menimbulkan efek negatif baik secara fisik, mental, maupun psikososial. ${ }^{3}$

Secara realita, mengonsumsi minuman beralkohol pada beberapa daerah di Indonesia sudah menjadi kebiasaan dan kebudayaan. Data Riskesdas menunjukkan daerah dengan prevalensi minum alkohol tertinggi di Sulawesi Selatan adalah Kabupaten Toraja Utara, yaitu 27,5\% dalam 12 bulan terakhir, atau 22,6\% dalam 1 bulan terakhir. Kebanyakan dari mereka mengonsumsi karena lingkungan sosialnya. Dari aspek budaya, tuak merupakan minuman yang dapat mempererat persaudaraan dan selalu disajikan dalam perayaan pesta adat. Proses difusi terjadi ketika orang Toraja mengundang pendatang di upacara adat dan menawarkannya minuman tuak. Demi menghormati tamu, undangan akan ikut mengonsumsi tuak dan akhirnya terbiasa dengan hal tersebut. Terdapat juga kebiasaan mengonsumsi tuak dengan bir. Mereka yang berstatus sosial ekonomi tinggi biasanya menyediakan bir di setiap acaranya. Maka dapat dikatakan bahwa konsumsi tuak di Toraja Utara merupakan bagian daripada tradisi masyarakat, baik pada perayaan pesta adat maupun dikegiatan sehari-hari. ${ }^{4}$

Selain di Sulawesi, tuak adalah minuman beralkohol tradisional di daerah Sumatera Utara, khususnya di Batak Toba, dengan kandungan alkohol 4\%. Tuak terbuat dari batang kelapa atau aren dan diambil airnya kemudian dicampur dengan raru. Minum tuak merupakan bagian dari

\footnotetext{
${ }^{1}$ Nugroho, Christianto Adhy, "Pengaruh minuman beralkohol terhadap jumlah lapisan sel spermatogenik dan berat vesikula seminalis mencit." Jurnal Ilmiah Widya Warta 33.1 (2009), hlm. 56-60

2 Minuman beralkohol tradisional, diproduksi secara tradisional dengan resep turun temurun yang diminum untuk merayakan acara keagamaan atau tradisi.

${ }^{3}$ Lestari, Tri Rini Puji. "Menyoal Pengaturan Konsumsi Minuman Beralkohol di Indonesia." Aspirasi: Jurnal Masalah-masalah Sosial 7.2 (2019), hlm. 127-141.

${ }^{4}$ Riskiyani, Shanti, Miftahul Jannah, and Arsyad Rahman. "Aspek Sosial Budaya Pada Konsumsi Minuman Beralkohol (Tuak) Di Kabupaten Toraja Utara." Media Kesehatan Masyarakat Indonesia 11.2 (2015), hlm. 76-85.
} 
tradisi yang sudah turun temurun di desa Bukit Selamat dan sangat sulit dihilangkan dari adat masyarakat. Desa Bukit Selamat adalah kategori berat $84,8 \%$ dengan 55,4\% tergolong minuman baru tuak. Orang dengan persepsi sehat negatif sebanyak 66,3\%. Ada hubungan antara persepsi sehat dengan kebiasaan mengkonsumsi tuak masyarakat Desa Bukit Selamat. 5

Padahal alkohol dapat menyebabkan efek kesehatan yang serius dari mabuk, ada tiga hal yang terdapat dari minuman beralkohol adalah; Pertama, penambahan berat badan, tekanan darah tinggi, penurunan sistem kekebalan tubuh, kanker, penyakit jantung, masalah pernapasan dan gangguan hati. Kebiasaan minum tuak Di sisi lain, rentetan peristiwa kematian akibat penyalahgunaan minuman beralkohol sampai saat ini masih sering terjadi. Indonesia sebagai negara hukum dalam konstitusinya telah menjamin bahwa setiap orang berhak hidup sejahtera lahir batin, bertempat tinggal, dan mendapatkan lingkungan hidup yang baik dan sehat serta berhak memperoleh pelayanan kesehatan. Dua hal yang bertolak belakang tersebut menggambarkan efektifitas hukum belum maksimal diterapkan dalam peraturan perundang-undangan berkaitan dengan pengendalian minuman beralkohol. ${ }^{6}$ Pemerintah belum mengatur suatu undang-undang khusus untuk mengendalikan produksi, dengan interpretasi dan perluasan sistematis terhadap Undang-Undang Pemerintah Daerah Nomor 23/2014, Peraturan Menteri Perindustrian nomor 63/M-IND/PER/7 /2014 tentang Penertiban dan Pengendalian Industri dan Mutu Minuman, Permendag No. 20/M-Dag/Per/4/2014 Tentang Penertiban dan Pengawasan Penyediaan, Peredaran dan Penjualan Minuman Beralkohol, Kepala Badan Pengawas Obat dan Makanan Peraturan Nomor HK.03.1.23.04.12.2205 tentang Pedoman Pemberian Sertifikat Produksi Pangan Industri Rumah Tangga. Tanggung jawab Pemerintah Daerah dalam pengendalian produksi minuman beralkohol tradisional, sehingga pemerintah daerah memiliki kewenangan untuk mengontrol peredaran minuman beralkohol tradisional dengan menerapkan penegakan peraturan terhadap kegiatan usaha yang

\footnotetext{
${ }^{5}$ Fentiana, Nina. "Kebiasaan Mengkonsumsi Tuak dan Persepsi Sehat Masyarakat Desa Bukit Selamat Kecamatan Besitang Kabupaten Langkat Propinsi Sumatera Utara." Jurnal Ilmiah Universitas Batanghari Jambi 19.3 (2019), hlm. 620-622.

6 Yulianto, Lukman. "Harmonisasi Hukum Tentang Pengawasan Dan Pengendalian Minuman Beralkohol." Jurnal Ilmu Hukum Mizan 1 (2012).
} 
melanggar izin perdagangan dengan menjual minuman beralkohol tradisional. ${ }^{7}$

Kajian ini bermaksud untuk membahas mengenai permasalahan bagaimana pengaturan minuman beralkohol di Indonesia serta bagaimana penegakan hukum pengaturan minuman beralkohol di Indonesia. Masalah ini menjadi penting untuk dikaji mengingat sampai sekarang pengaturan mengenai minuman beralkohol masih tersebar secara sektoral di berbagai peraturan perundang-undangan. RUU tentang Larangan Minuman Beralkohol diharapkan dapat mengakomodir semua permasalahan hukum mulai dari pengendalian minuman beralkohol sampai pada batasan konsumsi minuman beralkohol. Penegakan hukum pengaturan minuman beralkohol belum optimal terealisasi di Indonesia. Hal ini disebabkan beberapa faktor efektivitas hukum belum terpenuhi secara maksimal.

\section{Hasil dan Pembahasan}

Minuman beralkohol pada Islam atau disebut khamr adalah haram hukumnya termasuk segala jenis kegiatan yang berkaitan dengan minuman beralkohol adalah haram termasuk jual belinya. Perbedaan antara realita penerapan peraturan yang diterapkan oleh pemerintah daerah dengan yang telah di Firmankan oleh Allah swt., salam surat alNahl ayat 67, surat al-Baqarah ayat 219, surat al-Nisa ayat 43 , dan surat al-Maidah ayat 90 .

Hal ini juga direspon dalam Fatwa Majelis Ulama Indonesia Nomor 11 Tahun 2009 Tentang Hukum Alkohol, bahwa pemanfaatan alkohol sebagai bahan campuran pada makanan, minuman, obat-obatan dan kosmetika dihukumi mubah (dibolehkan) dengan syarat tidak melebihi kadar yang telah ditentukan oleh medis. Akan tetapi dalam penggunaan alkohol dalam campuran pembuatan produk secara berlebihan dapat menimbulkan memabukkan, menimbulkan efek samping maka hukumnya haram karena dapat membahayakan konsumen atau masyarakat. Sedangkan analisis mașlaḥah terhadap Tingkat Kebutuhan Penggunaan Alkohol dalam Fatwa Majelis Ulama Indonesia (MUI) No.11 Tahun 2009 tentang Hukum Alkohol Dalam mengambil kemaşlaḥatan, bahwa belum ditemukan bahan pelarut selain alkohol, maka dalam hal mengkonsumsi produk beralkohol diperbolehkan jika ada kemaslahatan

7 Alfianti, Luffita. "Upaya Pemerintah Daerah Dalam Pengendalian Produksi Minuman Beralkohol Tradisional." Yuridika 33.1 (2018), hlm. 93-117 
yang timbul setelahnya,dan masyarakat khususnya umat lebih lebih berhati-hati dalam mengkonsumsi produk yang menggunakan bahan alkohol, agar tujuan agama Islam dalam kemaslahatan umat dapat tercapai yaitu melindungi agama, jiwa, akal, keturunan dan harta dapat tercapai.

Minuman beralkohol adalah minuman yang mengandung etanol yang diproses dari bahan hasil pertanian yang mengandung karbohidrat dengan cara fermentasi dan destilasi atau fermentasi tanpa destilasi. Menurut Peraturan Menteri Kesehatan Republik Indonesia No.86/1977, minuman beralkohol dibedakan menjadi 3 golongan yaitu Golongan A dengan kadar alkohol 1-5\%, Golongan B dengan kadar alkohol 5-20\%, dan Golongan C dengan kadar alkohol 20-55\%. Penen-tuan kadar etanol dalam minuman beralkohol diawali dengan proses destilasi untukmemisahkan etanol dari air dan komponen lainnya. Sebelum proses destilasi campuran ditambahkan dengan serbuk $\mathrm{MgO}$ atau $\mathrm{CaO}$ yang berfungsisebagai zat pengering karena dapat menghilangkan $5 \%$ air dari etanol dan dapat bereaksi dengan air membentuk etanol-kalsium hidroksida yang sukar larut. Berat jenis etanol diukur dengan menggunakan piknometer. Berat jenis etanol hasil pengukuran kemudian dikonversi menjadi kadar etanol menggunakan tabel farmakope. Kadar etanol dalam minuman beralkohol merk A sebesar 9,61\%, merk B 7,01\%, merk C 6,56\%, merk D 5,59\%, dan merk E 9,09\%. Kelima merk minuman tersebut dikategorikan ke dalam minuman beralkohol golongan B. ${ }^{8}$

Dewasa ini banyak produk dengan campuran alkohol yang beredar di pasaran terutama pada produk minuman. Setiap orang mempunyai batas toleransi terhadap alkohol yang dikonsumsinya. Apabila orang tersebut mengkonsumsi secara berlebih, maka akan terjadi dampak buruk bagi kesehatan. Diantaranya, merusak sistem kinerja otak, gangguan jantung, penyakit kanker, kera-cunan, bahkan kematian. Selain berdampak buruk bagi kesehatan, mengkonsusmsi alkohol secara berlebih mengakibatkan gangguan mental. Gangguan mental ini akan mengakibatkan perubahan perilaku seperti bertindak kasar, mudah marah, bahkan dapat melakukan pelanggaran atau tindakan kriminal. Permasalahannya adalah sering munculnyapara produsen ilegal yang

8 Memah, Meylin, Grace D. Kandou, and Jeini Ester Nelwan. "Hubungan antara kebiasaan merokok dan konsumsi alkohol dengan kejadian hipertensi di Puskesmas Kombi Kecamatan Kombi Kabupaten Minahasa." KESMAS 8.1 (2019). 
membuat minuman dengan kadar alkohol yang tinggi atau menyalahi aturan batas kadar alkohol yang telah ditentukan. DEPKES dan BPOM dalam menentukan label kadar alkohol.

Minuman keras adalah minuman yang mengandung kadar etanol tinggi, yang dimaksud dengan minuman beralkohol adalah minuman yang mengandung etanol yang diproses dari bahan hasil pertanian yang mengandung karbohidrat dengan cara fermentasi dan destilasi atau fermentasi tanpa destilasi, baik dengan cara memberikan perlakuan terlebih dahulu atau tidak, menambahkan bahan lain atau tidak, maupun yang diproses dengan cara mencampur konsentrat dengan alkohol atau dengan cara pengenceran minuman mengandung alkohol. ${ }^{9}$

Untuk menyikapai terhadap realita yang ada di tengah-tengah masyarakat, pertama, bahwa minuman beralkohol ucap kali menjadi tradisi bagi masyarakat tertentu, namun di sisi lain juga menimbulkan kemudharatan dan meningkatnya angka kematian yang disebabkan karena minuman beralkohol, disisi lain pula muncunya banyak jenis makanan yang menggunakan alkohol dengan banyak jenisnya dan kadarnya.

Syari'ah Islam bertujuan untuk menyikapi realita masyarakat, yang menjadi misi ajaran Islam itu sediri baik yang bersifat dharuriyah (primer), hajjiyah (skunder) dan tahsiniyah (tersier), ${ }^{10}$ Maqāsid Syari'ah, sangat penting untuk memahami redaksi Al-Qur'an dan Sunnah, menyelesaikan dalildalil yang bertentangan dan yang sangat penting lagi adalah untuk menetapkan hukum terhadap kasus yang tidak tertampung oleh AlQur'an dan Sunnah secara kajian kebahasaan. ${ }^{11}$ Secara dharuriyah tujuan hukum syara' adalah untuk menjaga agama, jiwa, akal, nasab dan harta. Karena sesungguhnya hukum adalah li jalbi al-mashalih wa li daf'i al-mafasid (mengambil kemaslahatan dan meniadakan kemudharatan). Syari'ah atau hukum Islam ditetapkan atas tiga asas, yaitu; Pertama, 'adamul haraj (meniadakan kesulitan), Kedua, taqlilut takalif (meringankan beban), Ketiga, at-tadarruju fittasyri', syari' at diterapkan secara berproses.

Imam Ghazali mengelompokkan maslahat menjadi tiga aspek, yaitu: Pertama, Maslahat dibedakan berdasarkan ada keabsahan normatif atau

\footnotetext{
9 Primadevi, Susan, and Dian Kresnadipayana. "Penetapan kadar etanol pada minuman beralkohol berbagai merk melalui pengukuran berat jenis." Biomedika 9.1 (2016), hlm. 7174 .

${ }^{10}$ Jalaluddin al-Suyuti, al-Asybāh al-Nazā'ir, (Bairut: Dār al-Fikr, tt.), hlm. 176

11 Amir Syarifuddin, Usul Fikih, jilid-2, (Jakarta: Logos Wacana Ilmu, 1999), hlm. 91
} 
kadar kekuatan dukungan nas kepadanya menjadi tiga macam, yaitu; a) Maslahat yang didukung keabsahannya dalam syarā' dan dapat dijadikan illat dalam qiyās. b) Maslahat yang didukung oleh syara' kebatalannya, c) Maslahat yang tidak mendapat dukungan dari syarä' dalam hal keabsahan maupun kebatalannya.12 Kedua, Dilihat dari aspek kekuatan maslahat (keabsahan fungsional) itu sendiri. Terhadap maslahat ini, Ghazali memberikan syarat-syarat pemberlakuannya; a) Kemaslahatannya sangat esensial dan primer (dharuriyah), b) Kemaslahatannya sangat jelas dan tegas (qat'iyyah), c) Kemaslahatannya bersifat universal (kuliyyah), d) Kemaslahatannya berdasarkan pada dalil yang universal dari keseluruhan qarinah (mu'tabarah). ${ }^{13}$ Jenis maslahat ini terkait erat dengan beberapa aspek penyempurna (takmîlan dan tatimmah). ${ }^{14}$

Dalam rumusan berbeda juga disebutkan, bahwa legalitas maslahah mursalah dalam kajian usul fikih harus di dasarkan pada kreteria-kreteria berikut ini. Pertama, Maslahah itu harus bersifat pasti, bukan sekedar rekaan atau anggapan bahwa ia memang mewujudkan suatu manfaat, atau mencegah terjadinya kemudharatan. Kedua, Maslahah itu bukan hanya kepentingan pribadi, atau sebagian kecil masyarakat, namun bersifat umum. Ketiga, Hasil penalaran maslahat itu tidak berujung pada pengabaian suatu prinsip yang telah ditetapkan oleh nash syari'ah..$^{15}$

Kreteria di atas, tidak menjadikan sebuah batasan terhadap maslahah bagi al-Tûfi, yang dikenal dengan tokoh Kontroversial, dari mazhab Hanbalī dinilai berlebihan dalam menilai maslahah. ${ }^{16}$ Mengingat dalam pandangan al-Tûfi, pembagian maslahah sebagaimana pembahasan di atas, sebenarnya tidak ada dengan alasan tujuan syari'ah adalah kemaslahatan, maka dengan demikian, segala bentuk kemaslahatan didukung atau tidak didukung oleh teks suci harus dicapai tanpa merinci kedalam pembagian maslahah secara kategoris. ${ }^{17}$

\footnotetext{
12 Wahbah Zuhaili, Usul al-Fiqh al-Islami, jilid II, (Bairut: Dar al-Fiqr, 1987), hlm. 769

${ }^{13}$ Hamka Haq, al-Syatibi, Aspek Teologis Konsep Maslahah dalam Kitab al-Muwāfaqāt, (T. Tp. Penerbit Erlangga, 2007), hlm. 251

14 Wahbah Zuhaili, Usûl al-Figh al-Islami,Op.Cit., hlm. 170-171

15 Anang Haris Imawan, "Refleksi Pemikiran Hukum Islam: Upaya-Upaya Menangkap Simbol Keagamaan" dalam Anang Haris Himawan (peny). Epistimologi Syara' Mencari Format Baru Fikih Indonesia, cet-1, (Yogyakarta: Pustaka Pelajar, 2000), hlm. 84

${ }^{16}$ Mustafa Ahmad Zarqa', al-Istislah wa al-Masa'il al-Mursalah fi al-Syari'ah al-Islamiyah wa Usul Fikih, diterjemahkan oleh Ade Dedi Rohayana, Hukum Islam dan Perubahan Sosial, cet-1, (Jakarta: Reora Cipta, 2000), hlm. 81

17 Saifuddin Zahri, Usul Figh: Akal Sebagai Sumber Hukum Islam, cet-2, (Yogyakarta:
} 
Seperti halnya keharaman khamr, pada masa Rsulullah saw., telah ditetapkan secara tadrijiyan (beransur-ansur). Pertama, sebagaimana firman Allah swt., dalam surat al-Nahl ayat 67 (yang menerangkan bahwa khamr berasal dari perasan kurma dan anggur), ada sebagian yang menjadikannya sebagai minuman yang memabukkan, namun ada yang menjadikannya sebagai minuman yang halal. Kedua, firman Allah swt., surat al-Baqarah: 219 (menerangkan bahwa khamr banyak manfaatnya, namun mudharat dan dosanya lebih besar daripada manfaatnya). Ketiga, firman Allah dalam surat al-Nisa: 43 (menerangkan tentang larangan shalat ketika dalam keadaan mabuk, sampai kita sadar atas apa yang kita ucapkan). Keempat, firman Allah swt., surat al-Ma'idah: 90 (menerangkan bahwa khamar adalah perbuatan syaithan, maka kita harus menghindarinya.

Secara teoritis, metode istinbat, seperti qiyās, istihsan, dan maslahah mursalah adalah metode-metode pengembangan hukum Islam yang didasarkan atas maqasid syari'ah. Qiyās, misalnya, baru bisa dilaksanakan bilamana dapat ditemukan maqasid syari'ah-nya yang merupakan alasan logis ('illat) dari suatu hukum. Sebagai contoh, tentang kasus diharamkannya minuman khamar (QS. al-Māidah: 90). Dari hasil penelitian ulama ditemukan bahwa maqāsid syari'at dari diharamkannya khamar ialah "karena sifat memabukkannya yang merusak akal pikiran". Dengan demikian, yang menjadi alasan logis ('illat) dari keharaman khamar adalah sifat memabukkannya, sedangkan khamar itu sendiri hanyalah sebagai salah satu contoh dari yang memabukkan.

Dari sini dapat dikembangkan dengan metode analogi (qiyās) bahwa setiap yang sifatnya memabukkan adalah juga haram. Dengan demikian, 'illat hukum dalam suatu ayat atau hadis bila diketahui, maka terhadapnya dapat dilakukan qiyās (analogi). Artinya, qiyās hanya bisa dilakukan bila mana ada ayat atau hadis yang secara khusus dapat dijadikan tempat meng-qiyās-kannya yang dikenal dengan al-maqīs 'alaih (tempat meng-qiyās-kan).

Jika tidak ada ayat atau hadis secara khusus yang akan dijadikan almaqis 'alaih, tetapi termasuk ke dalam tujuan syari' at secara umum seperti untuk memelihara sekurang-kurangnya salah satu dari kebutuhan di atas tadi, dalam hal ini dilakukan metode maslahah mursalah.

Pustaka Pelajar, 2011), h. 117 Fathurrahman Djamil. 1995. Metode Ijtihad Maelis Tarjīh Muhammadiyah. Jakarta: Logos Publishing House, tt.), cet. I. hlm. 35-47. 


\section{Kajian Minuman Keras}

Dalam tinjauan maqasid al-Syari'ah, ditetapkannya hukum adalah untuk kemaslahatan dan menolak kemudharatan, artinya bahwa analogi hukum qiyqs yang menetapkan 'illat bahwa sesuatu yang memabukkan adalah haram, sebagaimana keharaman khamar. Maka secara tidak langsung bahwa segala sesuatu jenis minuman yang memabukkan adalah diharamkan dengan berbagai motofnya. Hal ini bertujuan untuk menjaga agama, menjaga jiwa, menjaga akal, menjaga nasab dan menjaga harta, lima asas hukum ini menyertai setiap ada dan tiadanya 'illat hukum, sebagaimana dalam kaidah al-hukmu yaduuru ma'a illatii wujudan wa 'adaman.

Menjaga agama (hifdu al-din), keharaman khamar dan sejenisnya ditetapkan dalam surat al-Ma'idah ayat 90. Dengan final mengharamkan minuman yang memabukkan, karena itu merupakan perbuatan syaithan, artinya ketika seseorang menjalankan aturan dalam agama, maka ia kan mendapatkan keselamatan dunia akhirat, sebagaimana maksud dari syari'ah.

Menjaga jiwa, (hifdu al-nafs), Jiwa manusia haruslah dilindungi, sehingga agama melarang pada sesuatu yang mendatangkan kemudharatan. Pada hakekatnya setiap Warga Negara berhak untuk mendapatkan lingkungan hidup yang baik dan sehat. Sebagaimana secara tegas dinyatakan dalam ketentuan Pasal 28H ayat (1) Undang-Undang Dasar Negara Republik Indonesia Tahun 1945 (UUD NRI 1945) yang berbunyi: "Setiap orang berhak hidup sejahtera lahir dan batin, bertempat tinggal, dan mendapatkan lingkungan hidup baik dan berhak memperoleh pelayanan kesehatan"

Menjaga akal (hifdu al-aql), selaian merusak jiwa seseorang, minuman yang memabukkan atau beralkohol dapat merusak akal, dan melakukan tindakan yang dilarang. Akhir-akhir ini kita sering dipertontonkan oleh kematian, pemerkosaan, kekerasan, pertikaian dan kejahatan lainnya yang diakibatkan oleh minuman beralkohol. Indonesia mengalami darurat minuman beralkohol karena implikasi yang terjadi dari minuman ini sangat besar mudhorotnya dibandingkan dengan manfaat yang diterima baik oleh masyarakat ataupun oleh negara. Hal ini selaras dengan Firman Allah dalam Al Quran Surat Almaidah ayat 90 yang menegaskan minuman khamar termasuk perbuatan syaitan. 
Menjaga keturunan (hifdu al-nasab atau al-nasl). Bahaya minuman keras, selain merusak saraf otak manusia juga dapat berakibat fatal pada keluarga dan anak, seperti tindakan KDRT. Jaminan konstitusi dan I'tibar yang dituangkan dalam al Quran memberikan rambu bagi kita bahwa mengkonsumsi alkohol tidak hanya berefek terhadap diri sendiri, tapi juga orang-orang disekitarnya seperti anak-anak. Karenanya kekerasan rumah tangga seringkali terjadi pada orang yang menyalahgunakan alkohol dan anak-anak mungkin menderita trauma jangka panjang akibat kebiasaan minum orangtuanya tersebut. Bahkan tak jarang kejahatankejahatabn besar juga berawal dari minuman ber alkohol. Sekitar 40 persen peminum beratmenunjukkan tanda-tanda depresi yang berujung pada pelanggaran hak asasi orang lain bahkan pembunuhan.

Menjaga harta (hifdu al-mal), sebagaimana larangan khamr, bahwa khamar itu banyak manfaatnya, namun mudharat dan dosanya lebih besar dari manfaatnya, secara untung dan rugi. Secara realita, manfaatnya seperti bahwa minuman keras atau beralkohol termasuk pajak tinggi bagi negara, namun karena mudharatnya yang leabih besar, bahwa orang yang telah teracuni oleh minuman keras, maka ia akan melakukan banyak hal untuk mendapatkannya, termasuk melakukan perbuatan yang dilarang agama, mencuri, menodong, membunuh, dan sebagainya. Berbahayanya minuman beralkohol sampai beberapa UU juga mengatur minuman beralkohol meskipun hanya sifatnya parsial dan tidak komprehensif. Salah satunya diatur dalam ketentuan UU 25 Tahun 2007 Pasal 12 ayat (3) disebutkan bahwa Pemerintah berdasarkan Peraturan Presiden menetapkan bidang usaha yang tertutup untuk penanaman modal, baik asing maupun dalam negeri, dengan berdasarkan kriteria kesehatan, moral, kebudayaan, lingkungan hidup, pertahanan dan keamanan nasional, serta kepentingan nasional lainnya. Pengaturan lain yang berkaitan dengan minuman beralkohol dapat dilihat dalam Pasal 111 dan Pasal 112 yang mengatur bahwa makanan dan minuman yang dipergunakan untuk masyarakat harus berdasarkan pada standar dan/atau persyaratan kesehatan. Selain itu, makanan dan minuman hanya dapat diedarkan setelah mendapat izin edar sesuai dengan ketentuan peraturan perundang-undangan.

Selain itu juga diatur dalam Pasal 300 KUHP yang menyebutkan bahwa: Diancam dengan pidana penjara paling lama satu tahun atau denda paling banyak empat ribu lima ratus rupiah: a. Barang siapa 
dengan sengaja menjual atau memberikan minuman yang memabukkan kepada seseorang yang telah kelihatan mabuk; dan di huruf $\mathrm{c}$ juga disebutkan Barang siapa dengan kekerasan atau ancaman kekerasan memaksa orang untuk minum minuman yang memabukkan.

Berdasarkan lampiran 1 Peraturan Presiden Nomor 36 tahun 2010 tentang Daftar Bidang Usaha yang Tertutup dan Bidang Usaha yang Terbuka dengan Persyaratan di Bidang Penanaman Modal maka ketentuan mengenai Industri Minuman Mengandung Alkohol (Minuman Keras, Anggur, dan Minuman Mengandung Malt) merupakan bidang industri yang tertutup untuk penanaman modal. Selanjutnya dalam lampiran Peraturan Presiden tersebut juga mengatur mengenai Perdagangan besar minuman keras/beralkohol (importir, distributor, dan subdistributor), Perdagangan Eceran minuman keras/ beralkohol, Perdagangan eceran kaki lima.

Pengertian maslahat secara etimologis, berarti kebaikan, kebermanfaatan, kepantasan, kelayakan, keselarasan, dan kepatutan. Kata al-maslahah dilawankan dengan kata al-mafsadah yang artinya kerusakan. ${ }^{18}$ Maslahat atau sering disebut maslahat mursalah, atau kerap juga disebut istislāh, yaitu suatu kemaslahatan yang tidak disinggung oleh syara' dan tidak pula terdapat dalil-dalil yang menyuruh untuk mengerjakan atau meninggalkannya, sedang jika dikerjakan akan mendatangkan kebaikan yang besar atau kemaslahatan. Mashlahat disebut juga mashlahat yang mutlak. Karena tidak ada dalil yang mengakui keabsahan atau kebatalannya. Jadi pembentuk hukum dengan cara mashlahat semata-mata untuk mewujudkan kemaslahatan manusia dengan arti untuk mendatangkan manfaat dan menolak ke-mudharat-an dan kerusakan bagi manusia. ${ }^{19}$

Kamus Besar Bahasa Indonesia membedakan antara kata maslahat dengan kemaslahatan. Kata maslahat, menurut kamus tersebut, diartikan sesuatu yang mendatangkan kebaikan, faidah dan guna. Sedangkan kata kemaslahatan mempunyai makna kegunaan, kebaikan, manfaat, kepentingan. Berdasarkan hal tersebut, jelas bahwa Kamus Besar Bahasa Indonesia melihat bahwa kata maslahat dimasukkan sebagai kata dasar,

${ }^{18}$ Asmawi, "Konseptualisasi Teori Maslahah," Jurnal Salam Filsafat dan Budaya Hukum Vol 12, no. 2 (Desember 2014): 314. Lihat juga Muhammad Roy Purwanto, "Kritik Terhadap Konsep Mashlahah Najm ad-Dîn at-Tûfi," Jurnal Madania vol 11, no. 1 (Juni 2015), hlm. 29.

${ }^{19}$ Moh. Mukri, Paradigma Maslahat dalam Pemikiran al-Ghazali, hlm. 181. 
sedangkan kata kemaslahatan dimasukkan sebagai kata benda jadian yang berasal dari kata maslahat yang mendapatkan awalan ke dan akhiran an. ${ }^{20}$

Kata masslahat secara bahasa berasal dari kata shalaha yang berarti baik dan menjadi lawan kata dari buruk, sehingga secara etimologis, kata maslahat digunakan untuk menunjukkan jika sesuatu itu baik atau seseorang menjadi baik.i Namun secara terminologis dalam usul fikih, baik dan buruk dalam pengertian maslahat ini menjadi terbatasi. Sebagaimana dalam buku Amir Syarifuddin dinyatakan; 1) Sandaran maslahat adalah petunjuk syarâ' bukan semata-mata berdasarkan akal manusia yang sangat terbatas, mudah terprovokasi oleh pengaruh lingkungan dan hawa nafsu. 2) Baik dan buruk dalam kajian maslahat tiak hanya terbatas pada persoalan-persoalan duniawi melainkan juga urusan ukhrawi. 3) Maslahat dalam kacamata syara', tidak hanya dinilai dari kesenangan fisik semata-mata, namun juga dari sisi kesenangan rûhaniyah. ${ }^{21}$

Para ulama yang menjadikan maslahat sebagai salah satu dalil syara', menyatakan bahwa dasar hukum maslahat, berdasarkan:

1. Persoalan yang dihadapi manusia selalu tumbuh dan berkembang, demikian pula kepentingan dan keperluan hidupnya. Kenyataan menunjukkan bahwa banyak hal-hal atau persoalan yang tidak terjadi pada masa Rasulullah saw., kemudian timbul dan terjadi pada masamasa sesudahnya, bahkan ada yang terjadi tidak lama setelah Rasulullah saw., meninggal dunia. Seandainya tidak ada dalil yang dapat memecahkan hal-hal yang demikian berarti akan sempitlah kehidupan manusia. Dalîl yang dimaksud adalah dalil yang dapat menetapkan mana yang merupakan kemaslahatan manusia dan mana yang tidak sesuai dengan dasar-dasar umum dari agama Islam. Jika hal itu telah ada, maka dapat direalisir kemaslahatan manusia pada setiap masa, keadaan dan tempat.

2. Sebenarnya para sahabat, tabi'in, tabi'it tabi'in dan para ulama yang datang sesudahnya telah melaksanakannya, sehingga mereka dapat segera menetapkan hukum sesuai dengan kemaslahatan kaum muslimin pada masa itu. Khalîfah Abû Bakar telah mengumpulkan

\footnotetext{
20Imron Rosyadi, "Pemikiran Asy-Syâtibî tentang Maslahah Mursalah," Jurnal Profetika Studi Islam vol 14, no. 1 (Juni 2013), hlm.82.

${ }^{21}$ Amir Syarifuddin, Usul Fikih, 2 (Jakarta: Logos Wacana Ilmu, 1999),hlm. 91.
} 
Alquran. Khalîfah Umar telah menetapkan talak yang dijatuhkan tiga kali sekaligus jatuh tiga, padahal pada masa Rasulullah saw., hanya jatuh satu. Khalifah Utsman telah memerintahkan penulisan al-Qur'an dalam satu mushaf. Khalîfah Ali pun telah menghukum bakar hidup golongan Syi'ah Rafidhah yang memberontak, kemudian diikuti oleh para ulama yang datang sesudahnya. ${ }^{22}$

Obyek maslahat, ialah kejadian atau peristiwa yang perlu ditetapkan hukumnya, tetapi tidak ada satupun nash (al-Qurân dan al-Sunnah) yang dapat dijadikan dasarnya. Prinsip ini disepakati oleh kebanyakan pengikut madzhab yang ada dalam fiqh, demikian pernyataan Imâm alQarafi al-Thûfî dalam kitabnya Maśalihul Mursalah menerangkan bahwa Masalihul Mursalah itu sebagai dasar untuk menetapkan hukum dalam bidang mu'ämalah dan semacamnya. Sedang dalam soal-soal ibadah adalah Allah Swt., untuk menetapkan hukumnya, karena manusia tidak sanggup mengetahui dengan lengkap hikmah ibadat itu. Kaum muslimîn beribadat sesuai dengan ketentuan-Nya yang terdapat dalam al-Qurân dan Hadith. ${ }^{23}$

Sejalan dengan batasan terhadap pengertian maslahat secara umum inilah, dalam teori hukum Islam atau yang disebut Islamic legal yurisprodence diperkenalkan tiga macam maslahat, yaitu maslahat mu'tabarah, maslahat mulghah dan maslahat mursalah. ${ }^{24}$ Maslahat mu'tabarah, didefinisikan sebagai maslahat yang diungkapkan secara langsung baik dalam al-Qur'an maupun hadis Nabi. Sedangkan maslahat mulghah, adalah maslahah yang bertentangan dengan ketentuan yang termaktub dalam alQur'an dan al-Hadits. Adapun maslahat mursalah adalah maslahat yang tidak ditetapkan dalam al-Quran dan hadis maupun juga tidak bertentangan dengan kedua sumber tersebut. ${ }^{25}$

Ada empat hal yang menjadi tujuan dan mendorong fuqahā dalam menggunakan istislāh, yaitu; 1) Jalb mashâlih, (menarik maslahat) yaitu perkara-perkara yang di diperlukan masyarakat untuk membangun kehidupanmanusia di atas pondasi yang kokoh. 2) Dar'u mafâshid,

\footnotetext{
${ }^{22}$ Amir Syarifuddin, hlm. 181.

${ }^{23}$ Amir Syarifuddin, hlm. 182.

${ }^{24}$ Amir Mu'allim dan Yusdani, Konfigurasi Pemikiran Hukum Islam (Yogyakarta: UII Press, 2001), 68. Lihat juga Hamzah K, "Revitalisasi Teori Maslahat Mulghâh Al-Tûhfî Dan Relevansinya dalam Pembentukan Perundang-Undangan di Indonesia," Jurnal ALAHKAM vol 15, no. 4 (Januari 2015), hlm. 27.

${ }^{25}$ Amir Mu'allim dan Yusdani, Konfigurasi Pemikiran Hukum Islam, hlm. 68-69.
} 
(menolak mafsadat) yaitu perkara-perkara yang memudharatkan manusia baik individu maupun kelompok, baik berupa materi maupun moral. 3) Syadz dzari'ah, (menutup jalan) yaitu menutup jalan yang dapat membawa kepada menyia-nyiakan perintah syari'ah dan memenipulasinya, atau dapat membawa kepada larangansyarâ' meskipun tanpa disengaja. 4) Taghayyur al-azman, (perubahan zaman) yaitu kondisi manusia, akhlakakhlak, dan tuntutan-tuntutan umum yang berbeda dari masa sebelumnya. ${ }^{26}$

Keempat prinsip tersebutlah yang menjadi urgen untuk digunakankan metode maslahat dalam menyikapi masalah-masalah kontemporer, sehingga Islam ${ }^{27}$ menjadi rahmatan li al-'̂alamin, mampu menyikapi situasi dan kondisi dalam keadalan arif bersifat dinamis dan berkeadilan.

Imam Malik sebagai orang yang pertama kali menggunakan teori maslahat, berpendapat bahwa maslahat yang dapat dijadikan sebagai sumber hukum harus memenui beberapa kreteria, yaitu adanya kesesuaian dengan tujuan syâri'yang secara umum didukung serta tidak bertentangan dengan nash. ${ }^{28}$ Pandangan al-Tûfi tentu berbeda terhadap pandangan terhadap maslahat secara umum yang telah dikemukakan oleh para ulama' termasuk al-Ghazali. Jika para ulama' selain al-Tûfi memaknai eksistensi maslahat yang masih dalam lingkaran syarâ', maka alThûfi lebih jauh melangkah dan cenderung melandaskan konstelasimaslahatpada superioritas oleh akal, karena akal manusia menurut al-Tûfi lebih objektif dalam memposisikan kreteria maslahatdibandingkan dengan pertentangan antara nash-nash syar'i. sehingga dengan demikian, validitas kehujahan maslahat harus diprioritaskan atas dalil-dalil lain termasuk nash syar'i. ${ }^{29}$

Argument al-Tûfi berdasarkan pada hadits nabi yang berbunyi $l \hat{a}$ dharâra wa la dhirâra. Menurut al-Tûfi, hadits ini adalah prinsip syari'ah yang sangat asasi, karena maslahat pada hakekatnya adalah untuk mencegah kesulitan yang diperlukan guna memberikan kemudahan bagi

${ }^{26}$ Mustafa Ahmad al-Zarqa', Hukum Islam dan Perubahan Sosial; Setudi Komperatif Delapan Madzhab, trans. oleh Ade Dede Rahayu (Jakarta: Riora Cipta, 2000), hlm. 42.

${ }^{27} \mathrm{Nu}^{\prime}$ man al-Jughaini, Turūq al-Kasyfi 'an Maqāshid al-Syarì'ah (Yordania: Dār al-Nafa'is, 2000), 8.

${ }^{28} \mathrm{Abu}$ Ishaq al-Syatibi, al-I'tisām, II (Riyadh: al-Haditsah, t.t.), hlm. 129.

${ }^{29}$ Muhammad Muslehuddin, Philosophy of Islamic Law and The Orientalist: A Komperative Studi of Islamic Legal System, trans. oleh Yudian Wahyudi Asmin (Yogyakarta: Tiara Wacana Yogya, t.t.), 133. 
orang yang sedang menghadapi kesulitan. Maka konsekuensinya, jika ada nashdan ijmấ yang harus menyesuaikan dengan maslahat dalam kasus tertentu, maka hal tersebut harus dilakukan, namun sebaliknya, jika antara nash dan ijmấ bertentangan maslahat maka kedua dalil tersebut harus tunduk pada maslahat. ${ }^{30}$

Pandangan al-Tûfi ini berasumsi bahwa nash (al-Qur'an dan alsunnah), yang dibuat oleh al-Syâri', untuk kemaslahatan manusia dan tidak sebaliknya, namun jika terdapat argument yang menganggap nash tidak relevan, maka harus dikembalikan pada maslahat, namun demikian al-Tûfi hanya mendefinisikan dalam bidang muamalah dan 'âdat saja, karena wilayah ibadah hanya al-Syâri' yang secara mutlak mengaturnya.

Pengunggulan maslahat terhadap nashdan ijmâ' bagi al-Tûfi didasarkan pada beberapa argumen.

a. Kehujahan ijmấ masih diperselisihkan, sedangkan kehujahan maslahat telah disepakati oleh para ulama', sehingga mendahulukan sesuatu yang disepakati lebih utama daripada sesuatu yang masihdiperselisihkan. ${ }^{31}$

b. Nash memungkinkan bayak pertentangan sehingga menimbulkan perbedaan pendapat, sedangkan memelihara kemaslahatan secara substansial merupakan sesuatu yang hakiki, sehingga pengutamaan maslahat adalah sebab terjadinya kesepakatan yang dikehendaki oleh syarâ'.

c. Secara faktual terdapat beberapa nashyang ditolak oleh para sahabat karena berdasarkan pada pertimbangan maslahat, salah satunya adalah hadits Nabi yang artinya "Barang siapa yang mengucapkan kalimat la ilaha illallah maka masuk surga". Umar melarang penyebaran hadits ini karena berdasarkan pertimbangan kemaslahatan, andai saja lafadz ini disebarkan, maka akan timbul kemalasan untuk beribadah hanya dengan hanya mengandalkan hadits tersebut. ${ }^{32}$

Namun satu hal yang harus dicatat, dalam konteks maslahat ini. alTûfi membagi hukum Islam kedalam dua katagori, yaitu hukum Islam dan katagori ibadah yang maksud dan maknanya telah ditentukan syâri' sehingga akal manusia tidak mampuuntuk menalarnya secara detail.

\footnotetext{
${ }^{30}$ Muhammad Muslehuddin, Filsafat Hukum Islam al-Ghazali; Maslahah Mursalah dan Relevansinya dengan Pembaharuan Hukum Islam (Jakarta: Pustaka Firdaus, 2002), hlm. 90.

${ }^{31}$ Ahmad Hanif Suratmaputra, Filsafat Hukum, t.t., hlm. 91.

${ }^{32} \mathrm{Ahmad}$ Hanif Suratmaputra, hlm. 133.
} 
Selain katagori ibadah, al-Tûfi juga membagi hukum Islam kedalam katagori muamalat yang makna dan maksudnya dapat dijangkau oleh akal. Dalam katagori inilah maslahat menjadi pedoman baik dikala ada nashmaupun ijmấ atau pun tanpa adanya dua dalil tersebut. 33

Secara operasional, maslahat al-Tûfi khususnyadalam ranah mu'amalah ini dibangun atas empat prinsip, yaitu:

a. Istiqlâl al'uqûl bi idrâk al-masâlih wa al-mafâsid (akal semata-mata dapat mengetahui tentang kemaslahatan dan kemafsadatan).

b. Al-maslahah dalilun syar'iyyun mustaqillun 'an al-nusush (maslahat adalah dalil independen yang terlepas dari nash).

c. Majâl al'amal bi al-maslahat humâ al-muâmalat wa al-'âdat dûna al-ibâdat wa al-muqaddarah (ranah pengamalan maslahaadalah bidang muamalahdan adat bukan ibadah dan muqaddarah).

d. Al-maslahah aqwâ adillat al-syar'i (maslahatadalah dalil hukum Islam yang paling kuat). ${ }^{34}$

Dari penjelasan konsep maslahat yang dipaparkanal-Tûfi dan alGhazali, pada prinsipnya memiliki tujuan yang sama yaitu kemaslahatan bagi manusia dan menghindarkan kemudharatannya, al-Ghazali justru membagi maslahat pada tiga kreteria, yaitu; maslahat mu'tabarah, maslahat mulghahdan maslahat mursalah, pembagian ini tentunya berdasarkan analisa yang tajam oleh Ghazali. Justru al-Tûfi tidak berbicara pada tataran maslahat mu'tabarah, karena ia masuk dalam kreteria qiyâs yang justru bukan dari bagian maslahat yang dimaksud, al-Tûfi banyak mengembangkan penalaran dan logika dalam menentukan kemaslahatan, karena akal manusia pada dasarnya dapat membedakan antara yang maslahat dan mudharat. Al-Tûfi menganggap bahwa akal lebih tinggi nilainya dalam penilaian nash, dan inilah yang mungkin kemudian bahwa al-Tûfi dianggap berlebihan dalam memaknai konsep maslahat.

Meskipun demikian, al-Ghazali dan al-Tûfi sama-sama ulama hebat yang mampu mencetuskan suatu konsep serta mengembangkannya dalam menyikapi permasalahan agama di era kontemporer yang selalu berkembang dan kompleks, sedangkan nash(Alquran dan al-Sunnah) sebagai sumber hukum Islam belum memberikan dasar hukumnya.

\footnotetext{
${ }^{33}$ Yusuf al-Qaradhawi, Dirasah fi Figh Maqashid al-Syari'ah, trans. oleh Arif Munandar Riswanto (Jakarta: Pustaka al-Kautsar, 2007), 217. Ahmad Hanif Suratmaputra, Filsafat Hukum, hlm. 133.

34Saifuddin Zuhri, Usul Fikih, t.t., hlm. 125-127.
} 
Meskipun al-Tûfi memberikan konsep yang beda dibandingkan alGhazali, namun ia tetap masih memberikan pembatasan pada konsep maslahat hanya terbatas pada hal-hal mu'amalat dan 'âdat dan bukan wilayah ibadah dan muqaddarah (perkara yang sudah ada dalilnya).

Maslahat dalam kaca mata syari'at adalah maslahat yang bukan berdimensi material dan duniawi saja, tetapi juga berdimensi spiritual dan concern dengan masalah-masalah ukhrawi. Menurut Syātibī, menawarkan beberapa syarat untuk dapat melonggarkan perkara dan tidak menyempitkan, yaitu; 1) maslahat itu sesuai dengan maksud syarā', sehingga tidak akan terjadi pertentangan antara maslahat dan dalil-dalil hukum Islam. 2) maslahat itu memang masuk akal, sehingga apabila dihadapkan dengan orang yang punya nalar tinggi, ia akan menerimanya. 3) hasil penerapan maslahat itu akan dapat menghilangkan kesempitan atau kepicikan, yang memang tidak diinginkan oleh syara' ${ }^{35}$

Said Ramadān al-Butī, menjelaskan dengan panjang lebar kriteria maslahat menurut syari'ah. Beliau menyimpulkan bahwa maslahat mempunyai tiga kriteria:

a. Maslahat harus mengandung dua dimensi masa, yaitu dunia dan akhirat. Dalam istilah singkatnya bisa disebut sebagai maslahat yang berwawasan dunia dan akhirat. Bagi orang-orang yang tidak beriman, kehidupan akhirat dipandang absurd atau kadang-kadang dipahami sebagai kehidupan yang fatamorganik. Untuk itu mereka sering mengabaikan maslahat yang bersifat ukhrawi. Bagi orang-orang yang beriman, kehidupan akhirat dipandang sebagai kelanjutan dari kehidupan dunia. Karenanya mereka meyakini adanya maslahat atau manfaat yang bersifat ukhrawi, sebagaimana halnya mereka merasakan maslahat duniawi.

b. Maslahat tidak hanya terbatas pada sisi dan norma material semata, tetapi juga harus mengandung norma spiritual agar maslahat tersebut bisa memenuhi kebutuhan jasmani dan rohani. Sebagian Filosof menentang adanya maslahat rohaniah (yang bersifat spiritual). Karena maslahat rohani menurut pandangan mereka akan terwujud dengan sendirinya jika kebutuhan jasmani terpenuhi. Kebanyakan filosof tidak mempercayai maslahat yang bersifat spiritual ini. Karena itu setiap maslahat atau manfaat yang tidak bisa dinikmati secara

35 Abû Ishāq Ibrāhīm Ibnu Mûsāal-Syātibi, al-Muwwafaqat fi Usul al-Syarī'ah, (Bairut: Dār alKutub al-Ilmiyyah, tt.), hlm. 147 
material tidaklah disebut sebagai maslahat. Sejak jaman dulu semua orang mengerti bahwa riba itu tidak dilegalkan oleh agama. Tapi setelah mereka tahu bahwa ternyata riba mendatangkan keuntungan (kemaslahatan material), maka akhirnya mereka membolehkan riba demi untuk memenuhi kebutuhan jasmani yang bersifat material. Hal itu dikuatkan oleh analisa para ekonom.

c. Norma maslahat yang ditetapkan oleh agama merupakan dasar pijakan bagi maslahat-maslahat lainnya. Semua maslahat harus menginduk pada norma agama. Dan apabila pertentangan antara suatu kemaslahatan (baca: maslahat yang mutlak) dengan kemaslahatan agama, maka maslahat agama harus didahulukan demi menjaga dan melestarikan eksistensi agama. Pertentangan dimaksud tentunya berupa pertentangan antar norma. Norma atau nilai yang terdapat dalam maslahat agama berorentasi pada pandanganpandangan yang telah digariskan oleh al-Qur'an dan Sunah Nabi. Sedang norma kemaslahatan non agama tentu terlepas dari pandangan-pandangan keagamaan. ${ }^{36}$

\section{Penutup}

Tinjauan maqasid al-Syari'ah terhadap keharaman minuman beralkohol sebagaimana keharaman khamr dalam proses analogi hukum bertujuan untuk; Pertama, Mengambil kemaslahatan dan meniadakan kemudharatan, Kedua, bentuk saad al-Dzari'ah yaitu mencegah celah untuk melakukan tindakan yang membawa kemudhartan lebih besar dengan kaidah dar'ul mafasidi muqaddamun 'ala jalbil mashalih (mencegah kemudhartan lebih diutamakan daripada mengambil kemaslahatan). Hal ini dilakukan dmemi melindungi agama, jiwa, akal, nasab dan juga harta. Dari sinilah dipastikan bahwa segala minuman yang mendatangkan kemudharatan sebagaimana khamr dihukumi haram sebagaimana khamr, karena memiliki 'illat (argumen) hukum yang sama.

\section{Daftar Pustaka}

Badan Legislasi Dewan Perwakilan Rakyat Republik Indonesia, Naskah Akademik Rancangan Undang-Undang Tentang Larangan Minuman Beralkohol. Jakarta, 2014.

Ahmad Zarqa', Mustafa. al-Istislah wa al-Masa'il al-Mursalah fi al-Syari'ah al-Islamiyah wa Usul Fikih. Terj. Ade Dedi Rohayana, Hukum Islam dan

${ }^{36}$ Ramadan al-Bûti, dhawabit al-Maslahat fi al-Syari'ah al-Islamiyah, (Bairut: al-Muasasah alRisalah, 1986), hlm. 248. 
Perubahan Sosial, cet-1, Jakarta: Reora Cipta. 2000.

Anang Haris Imawan. Refleksi Pemikiran Hukum Islam: Upaya-Upaya Menangkap Simbol Keagamaan dalam Anang Haris Himawan (peny). Epistimologi Syara' Mencari Format Baru Fikih Indonesia. cet-1, Yogyakarta: Pustaka Pelajar. 2000.

Abû Ishāq Ibrāhīm Ibnu Mûsāal-Syātibi. al-Muwafaqat fi Usul al-Syarī'ah. Bairut: Dār al-Kutub al-Ilmiyyah, tt.

Amir Syarifuddin. Usul Fikih, jilid-2, Jakarta: Logos Wacana Ilmu. 1999.

Fathurrahman Djamil. Metode Ijtihad Maelis Tarjih Muhammadiyah. Jakarta: Logos Publishing House, tt., cet. I. 1995.

Hamka Haq al-Syatibi. Aspek Teologis Konsep Maslahah dalam Kitab alMuwāafaqāt. T. Tp. Penerbit Erlangga. 2007.

Jalaluddin al-Suyuti. al-Asybāh al-Nazā'ir. Bairut: Dār al-Fikr, tt.

Ramadan al-Bûti. dhawabit al-Maslahat fi al-Syari'ah al-Islamiyah. Bairut: alMuasasah al-Risalah. 1986.

Saifuddin Zahri. Usul Fiqh: Akal Sebagai Sumber Hukum Islam. cet-2, Yogyakarta: Pustaka Pelajar. 2011.

Wahbah al-Zuhaili. Usul al-Fiqh al-Islami. jilid II, Bairut: Dar al-Fiqr, 1987.

Christianto Adhy Nugroho. Pengaruh minuman beralkohol terhadap jumlah lapisan sel spermatogenik dan berat vesikula seminalis mencit, Jurnal Ilmiah Widya Warta 33.1. 2009.

Luffita Alfianti. Upaya Pemerintah Daerah Dalam Pengendalian Produksi Minuman Beralkohol Tradisional, Yuridika 33.1. 2018.

Lukman Yulianto. Harmonisasi Hukum Tentang Pengawasan Dan Pengendalian Minuman Beralkohol, Jurnal Ilmu Hukum Mizan 1. 2012.

Meylin Memah, Grace D. Kandou, and Jeini Ester Nelwan, Hubungan antara kebiasaan merokok dan konsumsi alkohol dengan kejadian hipertensi di Puskesmas Kombi Kecamatan Kombi Kabupaten Minahasa, KESMAS 8.1. 2019.

Nina Fentiana. Kebiasaan Mengkonsumsi Tuak dan Persepsi Sehat Masyarakat Desa Bukit Selamat Kecamatan Besitang Kabupaten Langkat Propinsi Sumatera Utara, Jurnal Ilmiah Universitas Batanghari Jambi 19.3.

Susan Primadevi and Dian Kresnadipayana. Penetapan kadar etanol pada minuman beralkohol berbagai merk melalui pengukuran berat jenis, Biomedika 9.1. 2016.

Shanti Riskiyani Miftahul Jannah, and Arsyad Rahman. Aspek Sosial Budaya Pada Konsumsi Minuman Beralkohol (Tuak) Di Kabupaten Toraja 
The Indonesian Journal of Islamic Law and Civil Law

Vol. 2, No. I, April, 2021, ISSN. Xxxx - xxxx

Utara, Media Kesehatan Masyarakat Indonesia 11.2. 2015.

Tri Rini Puji Lestari. Menyoal Pengaturan Konsumsi Minuman Beralkohol di Indonesia, Aspirasi: Jurnal Masalah-masalah Sosial 7.2. 2019. 